\title{
RESEARCH AND ANALYSIS OF KNOWLEDGE AND SKILLS OF HEALTH CARE PROFESSIONALS ON THE PREVENTION AND INFECTION CONTROL IN HEALTH CARE
}

\author{
Magdalena Ninova \\ Alexandrovska University Hospital
}

\begin{abstract}
In examining the need for training of health care professionals working in the Hospital, as well as students with education and qualification Bachelor's degree from the programs - Nurse and Midwife, in prevention and control of nosocomial infections conducted in five regions of Bulgaria and all Faculties of Health Care at medical universities it was established that there is a recognized need of developing criteria of safe care. The present study aims not so much to clarify the need for training but to determine the predisposition to continue to learn and develop in an appropriate direction, which will contribute to an even greater degree of professionalism of the activities to control and prevent nosocomial infections. The answers to all closedended questions in the survey aimed at clarifying the training practices passed for continuing education and the potential to participate in other trainings showed a definite need of training. At this stage it is difficult to determine whether this is a conscious stand or unconscious predisposition to training as a result of the established idea that it is something that should be done or just a fear of making a mistake.
\end{abstract}

Keywords: health care, prevention, infection control, nosocomial infections

\section{INTRODUCTION}

Nosocomial infections can affect about 1 in 10 patients in the European Union and lead to a significant increase in morbidity, mortality and costs. They are a problem of growing health and economic importance worldwide. They increase the duration of the underlying disease, increase mortality and decrease long-term survival among patients. Nosocomial infections significantly increase costs for inpatient and outpatient care and the risk of legal consequences for the hospital and staff.

Address for correspondence:

Milena Nankova

Faculty of Public Health

Medical University of Varna

84 Tsar Osvoboditel Blvd

Varna

e-mail:milena_viki@abv.bg
Importance of the problem

Nosocomial infections prolong the suffering of patients, increase healthcare costs and may have many other direct and indirect economic consequences, such as loss of productivity and disability. Although measurement of costs is difficult, the cost of hospital-acquired infection is high. The Court of Auditors of the United Kingdom estimated it to be $\mathfrak{E}$ 1 billion a year for the UK.

Costs are different for the different countries, and change over time, however, their relative size is similar. The Institute of Medicine of the United States predicted that the side effects in patients, including 15 hospital-acquired infections are responsible for 44.000 to 98.000 deaths annually in the United States at a price of \$17- \$ 29 billion.

Growth factor for nosocomial infections

Many factors contribute to the alarming increase in the levels of infections associated with health care. For example, the use of means that vio- 
late the normal defense mechanisms of the body. Persons receiving antimicrobial chemotherapy, which contributes to changes in the normal flora, and immunocompromised patients have a reduced ability to inhibit infections and are at particular risk.

Also, some organizational factors contribute, such as an increased number of beds, lack of screening upon admission of patients, reduced staff, improper hygiene of medical specialists and other hygienic requirements.

\section{SHORT HISTORICAL DATA}

\section{International historical aspect:}

In the UK and the US the position of a Nurse Specialist in Infection Control has been officially recognized.

In 1963, Sweden already had the first two nurses specialized in infection control.

In 1968, the Swedish Association for Sterilization and Infection Control, which was among the pioneers, was founded.

In 1972, associations in the US and Canada were united into the Association of Specialists in Infection Control (APIC).

In 1978, in the European office of the WHO in Copenhagen, there was an international conference titled: „The Role of the Infection Control Nurse-Specialist in the Monitoring (Surveillance) of Prevention and Control of Nosocomial Infections."

The conference ended with the adoption of a resolution establishing a multi-disciplinary, international association of infection control - the first significant step towards the creation of IFIC [International Federation for Control and Coordination of National Programs for VBI / nosocomial infections worldwide, preparation training materials and guidelines]. The Federation was founded in Sweden on August 31, 1987, after nearly 10 years of planning and organizational work.

\section{In Bulgaria there are four periods:}

First Period - Pre-Antiseptic

The first hospitals were temples, monasteries, Catholic authorities and other religious establishments called „asclepion“ (Greek god of medicine, Asclepius), „hosts“ (lat. Hospes - guest), „yatrey“ (gr. Iatros - healer), „nozokomeoni“ (gr. nosos - disease, comeo - care), „valetudinarii“ (lat. valetu- do - health), „hospital“ (lat. hospitalis - hospitality), „sick bay“ (shelters for people with leprosy), and later the big church hospitals with „hull“ (barracks) type large hospital rooms and a large number of patients in them. There was an incidence of nosocomial infections then called the "fire of St. Anthony". These patients were cared for by members of the clergy.

\section{Second Period - Antiseptic}

The individual isolation of the sick was introduced to practice via the so-called "boxing system." All this helped to reduce the proportion of nosocomial infections.

The Russian surgeon N. I. Pirogov (1810 - 1881) recommended a complete "system of isolating the sick “. Influenced by the discoveries of L. Pasteur, J. Lister (1827 - 1912), he introduced the spraying of bandages and surgical wounds with carbolic acid in surgery cases and became the father of antisepsis.

\section{Third Period - Antibiotic}

The discovery of sulfonamides in 1935 by G. Domagk revealed opportunities for antimicrobial therapy in the fight against nosocomial infections. The use of penicillin (discovered by A. Fleming in 1928) in clinical practice was the beginning of the third period to combat nosocomial infections, called „antibiotic“.

Fourth Period - Modern Hospital-Acquired (Nosocomial) Infections

This period began in the early twentieth century. In the 50 years of the twentieth century the first reports of increased purulent septic complications in the postoperative period appeared. In the 60 s called ,staphylococcus plague of the twentieth century", nosocomial infections with staphylococcal etiology were dominant.

In the 70s, the number of nosocomial infections caused by Gram - negative microorganisms gradually increased.

Training of medical professionals must be one of the main programs for prevention and control of nosocomial infections developed by the governing bodies.

Institutions Related to Prevention, Monitoring and Control of Nosocomial Infections Worldwide:

$\diamond$ Centers for Disease Control and Prevention (CDC) - United States 
Research and Analysis of Knowledge and Skills of Health Care Professionals on the Prevention and Infection Control ...

$\diamond$ Healthcare Infection Control Practices Advisory Committee (HICPAC) - the Committee provides periodic updating and development of existing recommendations in the field of infectious diseases and nosocomial infections;

$\diamond$ International Federation of Infection Control (IFIC) - an international federation for control and coordination of national programs for nosocomial infections worldwide, preparation of training materials and guidelines;

$\diamond$ European Centre for Disease Prevention and Control (ECDC) - its headquarters are in Stockholm, Sweden.

\section{Bulgarian Institutions:}

$\diamond$ Expert advice on prevention and control of nosocomial infections - advisory and monitoring body of the Ministry of Health

$\diamond$ National Center for Public Health and Analysis - advisory and monitoring body of the Ministry of Health

$\diamond$ Reference Center for Nosocomial Infections; $\diamond$ National Center of Infectious and Parasitic Diseases (NCIPD);

$\diamond$ Medical universities - providing scientific research, teaching on the subject;

$\diamond$ Regional Health Inspections (RHI) - providing methodological assistance to medical institutions;

$\diamond$ Hospital Committee on the Prevention and Control of Nosocomial Infections;

$\diamond$ Bulgarian Association for Prevention and Infection Control (BulNoso).

\section{AIM}

The aim of this paper is to explore the knowledge and awareness of health care professionals about the prevention and control of nosocomial infections in health care and on this basis to establish the average level of awareness.

\section{TASKS}

These objectives will be achieved through the following tasks:

Tabl. 1. Questionnaires sent to hospitals in Bulgaria

\begin{tabular}{|c|c|c|c|}
\hline Planning Region & $\begin{array}{l}\text { Populated } \\
\text { place }\end{array}$ & Health facility & $\begin{array}{l}\text { Number of sent } \\
\text { questionnaires }\end{array}$ \\
\hline \multirow[t]{2}{*}{ Northwestern Bulgaria } & Vratsa & MHAT Hristo Botev & 50 \\
\hline & Plovdiv & MHAT Plovdiv & 50 \\
\hline \multirow[t]{2}{*}{ South central } & Kardzhali & MHAT Dr. Atanas Dafovski & 50 \\
\hline & Momchilgrad & MHAT Dr. Sergey Rostovtsev & 50 \\
\hline Northeast & Varna & St. Marina University Hospital & 100 \\
\hline North Central & Ruse & MHAT Ruse & 50 \\
\hline \multirow[t]{11}{*}{ Southwest Bulgaria } & Sofia & $\begin{array}{c}\text { University Hospital for Active Treatment and } \\
\text { Emergency Medicine N.I.Pirogov }\end{array}$ & 100 \\
\hline & & University Hospital for Active Treatment St. Catherine & 30 \\
\hline & & $\begin{array}{l}\text { Specialized Hospital for Active Treatment in } \\
\text { Obstetrics and Gynecology Majchin Dom }\end{array}$ & 50 \\
\hline & & $\begin{array}{c}\text { University Hospital for Active Treatment Queen } \\
\text { Giovanna ISUL }\end{array}$ & 100 \\
\hline & & $\begin{array}{l}\text { University Specialized Hospital for Active Treatment } \\
\text { in Endocrinology Acad. Iv. Penchev }\end{array}$ & 30 \\
\hline & & $\begin{array}{l}\text { Specialized Hospital for Active Treatment of } \\
\text { Oncology Sofia District }\end{array}$ & 30 \\
\hline & & Second City Municipal Hospital & 30 \\
\hline & & Five City Municipal Hospital & 30 \\
\hline & & NTB Tsar Boris III & 30 \\
\hline & & UMHAT St. Iv. Rilski & 50 \\
\hline & & UMHAT Alexandrovska & 150 \\
\hline Total sent questionnaires & & & 980 \\
\hline Total number of open card & & & 835 \\
\hline
\end{tabular}


1. Studying the European and the Bulgarian regulatory framework on the prevention and control of nosocomial infections in health care;

2. Exploring the knowledge of health care professionals in medical institutions and students with a Bachelor's degree from the programs Nurse and Midwife on the prevention and control of nosocomial infections;

3. Examining the attitudes of health care professionals about participating in the system for continuous training on the prevention and control of nosocomial infections in health care.

\section{OBJECT OF RESEARCH}

We studied the competencies of health care professionals working in the Alexandrovska Hospital as well as students with a Bachelor's degree from the programs Nurse and Midwife on the prevention and control of nosocomial infections.

The first stage of the study consisted of prepared in advance questionnaires in order to conduct quantitative sociological research among health care professionals working in 15 hospital structures for active multi-profile treatment in: Sofia, Varna, Pleven, Kardzhali, Momchilovgrad, Pazardzhik as well as students majoring in the Nurse and Midwife programmes at the Medical University - Sofia, Medical University of Varna, the Shumen Affiliate of the Medical University of Varna, and the Medical University - Plovdiv.

The total number of surveyed was 1035, of the respondents 296 were students.

Questionnaires were sent to students majoring in the Nurse and Midwife programs at the Faculties of Public Health at the medical universities.

\section{PLACE AND TIME OF SURVEY}

The survey was conducted among students in Sofia, Plovdiv, Shumen and Varna. The study period was April - May 2016.

The survey among health care professionals was conducted in Sofia, Kardzhali, Momchilgrad, Pazardzhik, Varna, Ruse, Pleven, Vratsa and Plovdiv. The study period was within the month of March 2016.

\section{SURVEY METHODOLOGY}

The collection of primary information in the study was done using the following methods:

$\diamond$ Historical method - analysis of developments and trends in the prevention and control of nosocomial infections;

$\diamond$ Sociological method - we conducted an anonymous survey among students and health care professionals. For this purpose we used a questionnaire with specially prepared questionnaires for a research on knowledge, attitudes and evaluations of the respondents.

$\diamond$ Statistical method - introduction and processing were performed with Windows Excel. The used statistical methods have proven their suitability in the polls.

$\diamond$ Documentary method - used to gather information on the volume and type of tasks, structure and organization of health care and to study the regulation of medical practice.

ANALYSIS OF THE RESULTS (HEALTH CARE PROFESSIONALS)

The first group of characteristics focused on the basic demographic profile of the groups:

The overwhelming majority of respondents were female - $99 \%$. The specialties of respondents were as follows - 72 percent of respondents were nurs-

Tabl. 2. Questionnaires sent to students at the Faculties of Public Health at several medical universities

\begin{tabular}{|c|c|c|}
\hline $\begin{array}{l}\text { Populated } \\
\text { place }\end{array}$ & University & $\begin{array}{c}\text { Number of sent } \\
\text { questionnaires to students }\end{array}$ \\
\hline Sofia & Faculty of Public Health at the Medical University of Sofia & 100 \\
\hline Plovdiv & Faculty of Public Health at the Medical University of Plovdiv & 100 \\
\hline Shumen & Faculty of Public Health, Medical University of Varna, Shumen Affiliate & 50 \\
\hline Varna & Faculty of Public Health at the Medical University of Varna & 50 \\
\hline
\end{tabular}


es, the midwives were $24 \%$ and only $4 \%$ were radiologists. This score determined the prevalence of the attitudes of nurses at the expense of the other two majors, which is explained primarily by the overwhelming number of nurses with a relevance to the topic.

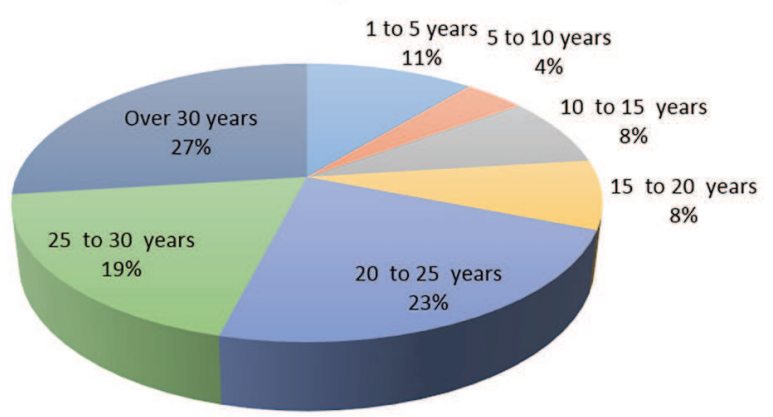

Fig. 1. Work experience

The second group of characteristics focused of the general knowledge and awareness of the health care professionals in regard to nosocomial infections:

The aim was to get a clear picture of the scope of information health care professionals handle in their daily activities, as it greatly determined their actions to reduce the risk of such infections and their readiness to overcome situations, such as an outbreak of nosocomial infections at the structure where they work (36\% correct answers).

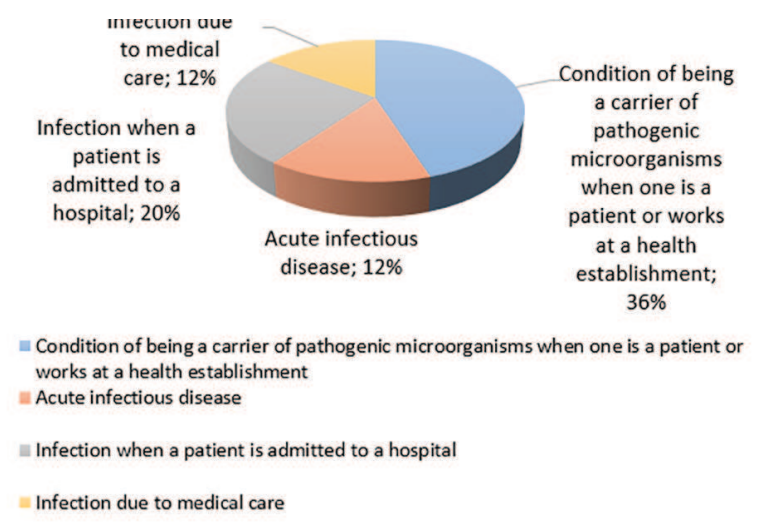

Fig. 2. What is a nosocomial infection?

The greatest percentage of preferences of respondents -68 , was in favor of the implementation of standard measures.

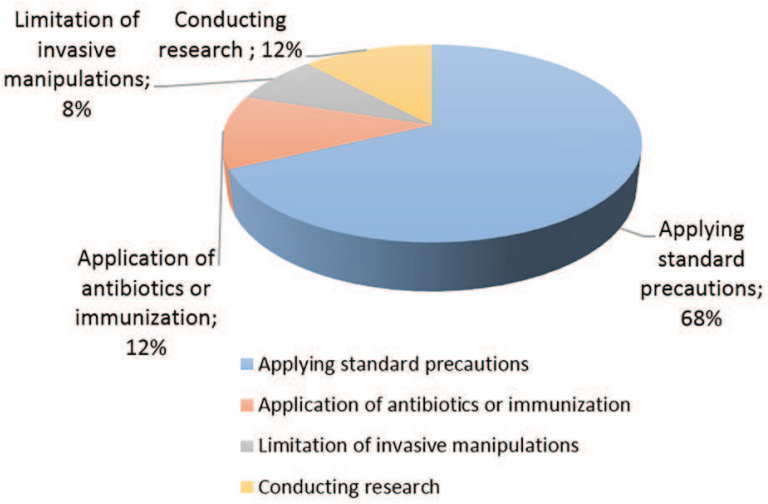

Fig. 3. What does the prevention of nosocomial infenctions include?

The next phase of the study sought further information on what respondents meant by „standard measures" through an additional questionnaire with open-ended questions.

An interesting reply to the question „What are the approaches to the prevention of nosocomial infections?" is the statement of $27 \%$ of the respondents that staff training is needed, which practically defined the second most important approach after "measures against sources of infection, indicated by $39 \%$ and with a higher number of supporters than "measures against pathways of infection“ $-24 \%$. This shows categorically that respondents recognize fully the insufficient awareness and training on the topic.

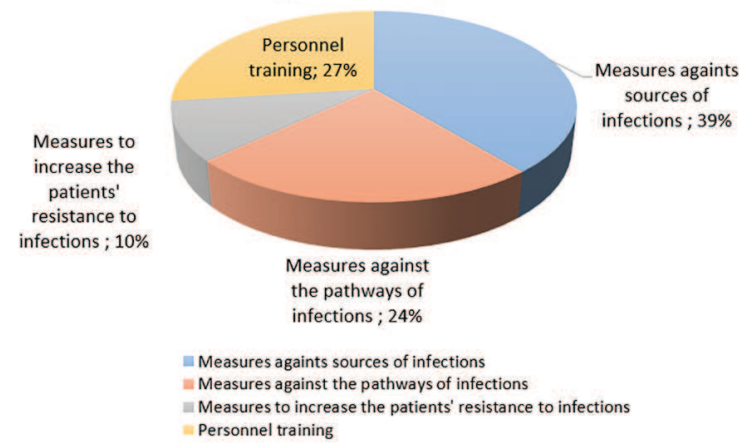

Fig. 4. What are the approaches to the prevention of nosocomial infections?

\section{STUDENTS}

The results show that students are not sufficiently informed and do not know enough about the 


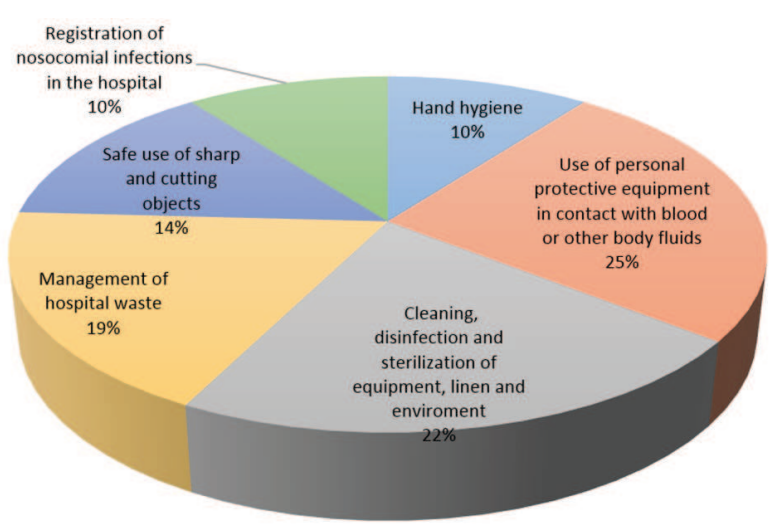

Fig. 5. Standard WHO precautions

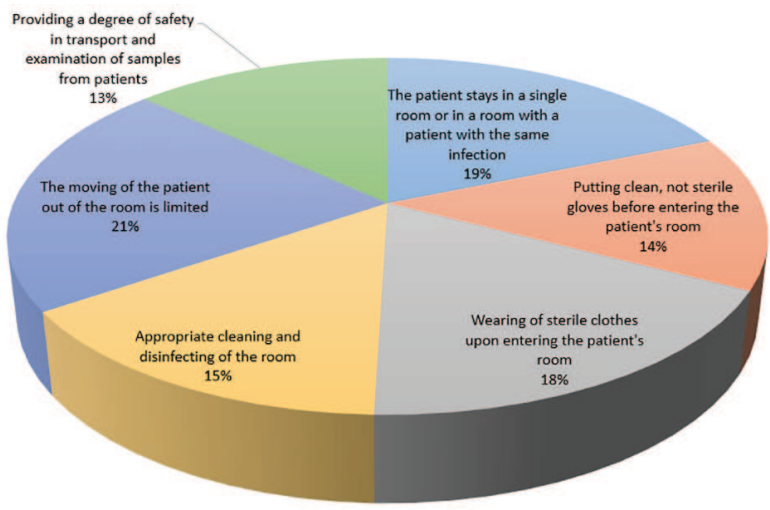

Fig. 6. What are additional measures that could be applied to prevent the development of nosocomial infections?

problem of nosocomial infections. They see the nature of nosocomial infections as largely incomplete. Students are not fully aware of their responsibility and the importance of the problem of nosocomial infections.

\section{PREVENTION PROBLEMS AND MEASURES}

The largest part of the questionnaire concerns issues related to prevention measures depending on whether they are related to staff, patients or visitors to the hospital. The purpose of these questions is to clarify what actually is known and especially what measures are applied on-site at clinics and wards of medical institutions employing the respondents of the survey.

Measures applied by the staff:

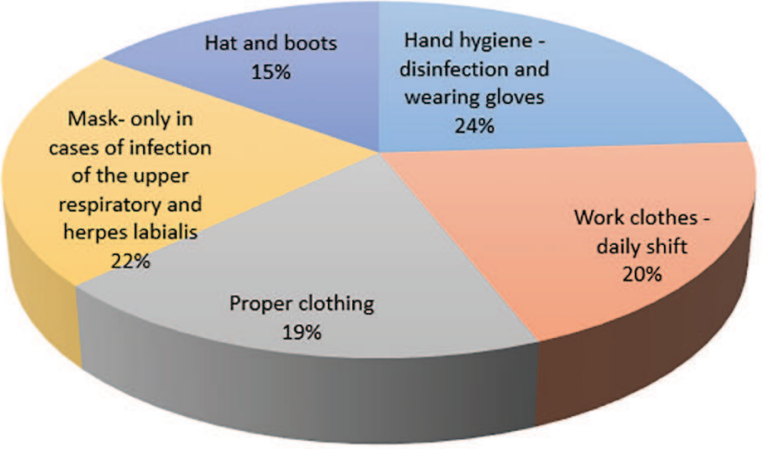

Fig. 7. What are the staff-oriented measures taken for the prevention of a nosocomial infection?

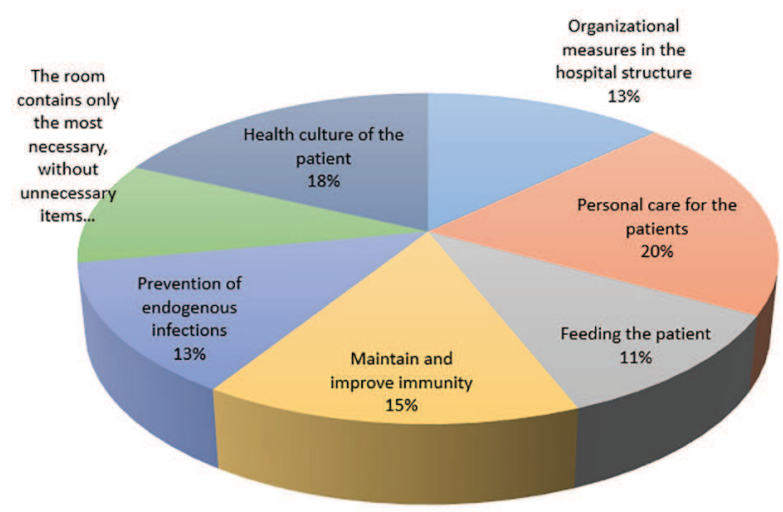

Fig. 8. What are the patient-oriented measures taken for the prevention of a nosocomial infection?

\section{RESULTS}

A more detailed research on the topic of prevention and control of nosocomial infections gives the initial impression that knowledge exist, but it is rather basic and formed on the basis of experience from the everyday activities rather than a conscious need of further professional development and an implementation of new, modern methods for the prevention of such infections.

Health care professionals, to a higher degree, and students are aware that such problem exists and it is a real risk in their work. It is mainly related to the amount of available information and the need to be familiar with new modern methods, which they can apply in the daily practice as part of the implementation of standard measures.

\section{CONCLUSIONS}

1. The legal basis in Bulgaria corresponds to the European legislation, with the expectation of a 
Research and Analysis of Knowledge and Skills of Health Care Professionals on the Prevention and Infection Control ...

more active participation by the Expert Council in regard to the prevention and control of nosocomial infections including development and provision of expertise on new regulatory standards and technologies related to the prevention and control of nosocomial infections to the National Health Insurance Fund, Ministry of Health, medical universities (programs for continuing education of medical professionals).

2. The results from the survey indicate that health care professionals, to a higher degree, and students are aware that such problem exists and it is a real risk in their work. It is mainly related to the amount of available information and the need to be familiar with new modern methods, which they can apply in the daily practice as part of the implementation of standard measures.

3. At this stage it is difficult to determine whether this is a conscious stand or unconscious predisposition to training as a result of the established idea that it is something that should be done. This results in positive responses to the questions, evident from the charts - $100 \%$ positive answers to the question about training of newcomers, 95\% confirmed the need of training in hospitals in regard to prevention nosocomial infections.

\section{SPECIAL THANKS}

Prof. Tzekomir Vodenitcharov, MD, PhD - Dean of the Faculty of Public Health, Medical University - Sofia

Prof. M. Alexandrova - Vice Dean of the Faculty of Public Health, Medical University - Sofia

Prof. Krassimir Vizev, MD, PhD - Vice Dean of the Faculty of Public Health, Medical University - Sofia

Prof. Sonya Tontcheva, MD, PhD - Head of the Shumen Affiliate of the Medical University of Varna, National Consultant on Health Care

Assoc. Prof. Kostadin Angelov, MD, PhD - Executive Director of University Hospital Alexandrovska JSC

Assoc. Prof. Tsvetan Velinov, MD, PhD-Head of Central Microbiology Laboratory
Maria Koumanova - Deputy Director of the University Hospital Alexandrovska JSC

Prof. Nelly Ribarova, MD, PhD - Faculty of Public Health, Medical University - Sofia

Prof. Stambolova - Department of Health Care, Faculty of Public Health, Medical University - Sofia

Assoc. Prof. Nicoletta Traykova, MD, PhD - Director of Medical College - Plovdiv

Anushka Dimitrova - Faculty of Public Health, Medical University - Sofia

Chief Nurse Viloleta Staneva - St. Marina University Hospital, Varna

Chief Nurse Diana Ivanova - Specialized Hospital for Active Treatment of Cancer, Sofia

Chief Nurse Daniela Goranova - University Hospital for Active Treatment and Emergency Medicine „N. I. Pirogov"JSC, Sofia

Charge Nurse Katia Hristova - University Hospital for Active Treatment „Dr. George Stransky“, Pleven

Chief Nurse Biljana Ognyanova - University Hospital for Active Treatment "St. Ivan Rilski“ JSC, Sofia

Chief Nurse Seynur Myumyun- Hospital for Active Treatment - "DrAtanas Dafovski , JSC - Kardzhali

Chief Nurse A. Dimitrova - Second Hospital for Active Treatment - Sofia

Chief Nurse Muratovska - Fifth Hospital for Active Treatment - Sofia

Chief Nurse Belgin Sadak- Hospital for Active Treatment „Sergei Rostovtsev" JSC, Momchilgrad

Chief Nurse Galina Tsinigarova - Hygeia Hospital, Pazardzhik

\section{REFERENCES}

1. Ribarova N, Mitova Y. Etiological characteristics of the nosocomial infection in different types of high risk hospital departmens in Bulgaria (1990-1998) Infectology, XXXVII, 2000, 11-17 9 (in Bulgarian).

2. Ribarova $\mathrm{N}$. The training of health care professionals - an important criterion for good medical practice regarding the prevention and control of nosocomial infection; National Scientific Symposium with International Participation "Selected problems of contemporary epidemiology", Sofia 04.12.2006. Proceedings. Sofia, 2007. 20-27; Health Management. 2006; 6(3); 63-66 (in Bulgarian). 
3. Ribarova N, Gladilova A. In-hospital (nosocomial) infections. Simelpress. Sofia; 2016 (in Bulgarian).

4. Mitova Y, Ribarova N, Minev M. Study on the distribution of post-operative infections of surgical wounds in high-risk hospital wards in Bulgaria during the period 2000-2004. Surgery. Sofia. 2006; 2: 11-16 (in Bulgarian).

5. Vodenicharov Ts. The ten principles of the health professional and the manaher. Simelpress; 2010 (in Bulgarian).

6. Vodenicharov Ts. Innovations in public health. Science and Society; 2012 (in Bulgarian).

7. Aleksandrova M. Contemporary trends in nurse training. Sofia; 2007 (in Bulgarian).

8. Aleksandrova M, Moskov A. Development of the nursing profession in Bulgaria and the influence of European countries. Nursing Science. 2001; 4: 20 23 (in Bulgarian).

9. Aleksandrova M. Planning, realization and evaluation of care defined in the nursing diagnosis. Public Health. Handbook for specialization of nurses. Gorex Press; 2001; 97-100 (in Bulgarian).

10. Aleksandrova M, Popov T. On certain techniques and innovation approaches to the continuing education of nurses. Pedagogical education in Bulgaria. State and trends. 2006; 440-444 (in Bulgarian).

11. Borisov V. Health management with health politics basis (in Bulgarian).

12. Borisov V. Health management. 2005 (in Bulgarian).

13. Borisov V, Glutnikova Z, Vodenicharov Ts. New public health. Sofia; 1995 (in Bulgarian).

14. Vodenicharov Ts, Glutnikova Z, Gateva L. Innovations in medical training. Sofia: Aquafix; 1997 (in Bulgarian)

15. Vodenicharov Ts, Mitova M. Medial pedagogics. Sofia; 1995 (in Bulgarian).

16. Vodenicharov Ts, Popova S. Medical ethics. Sofia: DAK; 2003 (in Bulgarian).

17. Vodenocharov Ts. The seven differences between the doctor and the manager. Sofia: DAK; 2003 (in Bulgarian).

18. Dimitrova E, Mitova M, Balkanska P. The training of nurses in Bulgaria and the European educational space. Health Management. Sofia; 2007 (in Bulgarian).
19. Krasteva N. Nursing care - theories and concepts. A textbook for nurses and midwives. Medical University of Plovdiv; 2006 (in Bulgarian).

20. Maslow A. Motivation and personality. Sofia: Kibea; 2001 (in Bulgarian).

21. Mitova M, Vodenicharov Ts. Pedagogical problems of medical education. Sofia; 1998 (in Bulgarian).

22. Sotirova D. Organizational behavior and culture. Faber (in Bulgarian).

23. Stambolova I. Nursing care in somatic diseases. Medical University of Sofia; 2012 (in Bulgarian).

24. Stambolova I. Ethical aspects of nursing and midwife care. Respecting the patient's rights. Rules for good nursing and midwife practice. Physicianpatient privilege and medical confidentiality. Foundations of nursing and midwife care. St. Zagora:KOTA; 2009 (in Bulgarian).

25. Stambolova I. Nurse training in the USA. Health Care. 2003: 52-55 (in Bulgarian).

26. Stambolova I. Public health, handbook for specialization of nurses. Gorex Press; 2001 (in Bulgarian).

27. Tornyova B. Moral culture of health care specialists. Ex-Press; 2006 (in Bulgarian).

28. Chakarova L, Mladenova S. The training for sustainable development in the field of medicine accordine to future medical personnel. Management and Education. 2012; 8(3): 209-212 (in Bulgarian).

29. Chaneva G. Quality of nursing care as a priority. Artik 2001; 2008 (in Bulgarian).

30. Chaneva G. Nursing conceptual models. Family nurse. BRC; 2009 (in Bulgarian).

31. Adal KA, Flowers RH, Anglim AM, et al. Prevention of nosocomial influenza. Infect Control Hosp Epidemiol. 1996;17:641вЂ“648.

32. Adler SP. Cytomegalovirus and child day care: evidence for an increased infection rate among daycare workers. N Engl J Med. 1989;321:1290-1296.

33. Adler SP. Hospital transmission of cytomegalovirus. Infect Agents Dis 1992;1:43-49.

34. Afif W, Huor P, Brassard P, Loo VG. Compliance with methicillin-resistant Staphylococcus aureus precautions in a teaching hospital. Am J Infect Control. 2002;30:430-433.

35. Ahlfors K, Ivarsson SA, Johnson T, Renmarker K. Risk of cytomegalovirus infection in nurses 
Research and Analysis of Knowledge and Skills of Health Care Professionals on the Prevention and Infection Control ...

and congenital infection in their offspring. Acta Paediatr Scand. 1981;70:819-823.

36. Alter SJ, Hammond JA, McVey CJ, Myers MG. Susceptibility to varicella-zoster virus among adults at high risk for exposure. Infect Control. 1986;7:448-451.

37. American Academy of Pediatrics. Summaries of infectious diseases: staphylococcal infections. In: Pickering LK, Baker CJ, Long SS, McMillan JA, eds. Red Book: 2006 Report of the Committee on Infectious Diseases. 27th ed. Elk Grove Village, IL: American Academy of Pediatrics; 2006:598-610.

38. American Academy of Pediatrics. Summaries of infectious diseases: group A streptococcal infections. In: Pickering LK, Baker CJ, Long SS, McMillan JA, eds. Red Book: 2006 Report of the Committee on Infectious Diseases. 27th ed. Elk Grove Village, IL: American Academy of Pediatrics; 2006:610-620.

39. American Academy of Pediatrics. Summaries of infectious diseases: varicella-zoster infections. In: Pickering LK, Baker CJ, Long SS, McMillan JA, eds. Red Book: 2006 Report of the Committee on Infectious Diseases. 27th ed. Elk Grove Village, IL: American Academy of Pediatrics; 2006:711-725.

40. American Academy of Pediatrics. Summaries of infectious diseases: cytomegalovirus infection. In: Pickering LK, Baker CJ, Long SS, McMillan JA, eds. Red Book: 2006 Report of the Committee on Infectious Diseases. 27th ed. Elk Grove Village, IL: American Academy of Pediatrics; 2006: 273-277.

41. An approach to the evaluation of quality indicators of the outcome of care in hospitalized patients, with a focus on nosocomial infection indicators. The Quality Indicator Study Group. Infect Control Hosp Epidemiol 1995;16:308-316.

42. Anderson GS, Penfold JB. An outbreak of diphtheria in a hospital for the mentally subnormal. J Clin Pathol. 1973;26:606-615.

43. Anderson LJ, Gillespie SM, Torok TJ, Hurwitz ES, Tsou CJ, Gary GW. Risk of infection following exposures to human parvovirus B19. Behring Inst Mitt. 1990;85:60-63.

44. Ansari SA, Sattar SA, Springthorpe VS, et al. Rotavirus survival on human hands and transfer of infectious virus to animate and nonporous inanimate surfaces. J Clin Microbiol. 1988; 26:1513-1518.
45. Ansari SA, Springthorpe VS, Sattar SA, et al. Potential role of hands in the spread of respiratory viral infections: studies with human Parainfluenza virus 3 and Rhinovirus 14. J Clin Microbiol. 1991; 29:2115-2119.

46. Singh A, Goering R, Simjee S, Foley S, Zervos M. Application of Molecular Techniques to the Study of Hospital Infection. Clin Microbiol Rev. 2006 Jul; 19(3): 512-530.

47. Arlian LG, Estes SA, Vyszenski-Moher DL. Prevalence of Sarcoptes scabei in the homes and nursing homes of scabietic patients. J Am Acad Dermatol. 1988;19:806-811.

48. Asano Y, Iwayama S, Miyata T, et al. Spread of varicella in hospitalized children having no direct contact with an indicator zoster case and its prevention by a live vaccine. Biken J. 1980;23:157-161. 